\title{
Rapid Hydrogen Generation from Aluminum-Water System Using Synthesized Aluminum Hydroxide Catalyst
}

\author{
Hong-Wen Wang and Ming-Ssu Chin
}

\begin{abstract}
Catalytic effect of $\mathrm{Al}(\mathrm{OH})_{3}$ on the hydrogen generation from $\mathrm{Al} /$ water system is evaluated. The $\mathrm{Al}(\mathrm{OH})_{3}$ powders are synthesized from various molar ratios of $\mathrm{Al}\left(\mathrm{NO}_{3}\right)_{3}$ : $\mathrm{NaOH}=1: 3 \sim 1: 5$. It was found that the $\mathrm{Al}(\mathrm{OH})_{3}$ catalyst derived from the ratio $\mathrm{Al}\left(\mathrm{NO}_{3}\right)_{3}: \mathrm{NaOH}=1: 3.5 \sim 1: 4$ in an ice bath exhibits the best catalytic effect and exerts the highest hydrogen generation rate. Over $95 \%$ yield of hydrogen from a 3 $\mathrm{g} \mathrm{Al} / 50 \mathrm{ml}$ water system (with $15 \mathrm{~g} \mathrm{Al}(\mathrm{OH})_{3}$ and $\mathrm{pH}=12$ ) can be generated within $100 \mathrm{~s}$. That is, by using specially synthesized $\mathrm{Al}(\mathrm{OH})_{3}$ catalyst at a $\mathrm{Al}: \mathrm{Al}(\mathrm{OH})_{3}: \mathrm{H}_{2} \mathrm{O}=3: 15: 50$ weight ratio, very rapid hydrogen generation rate $(\sim 667 \mathrm{ml} / \mathrm{g} \cdot \mathrm{Al} \cdot \mathrm{min})$, without using any alloying elements or extreme corrosive condition, can be realized.
\end{abstract}

Index Terms-Aluminum hydroxide, aluminum nitrate, hydrogen generation.

\section{INTRODUCTION}

Hydrogen generated from the reaction of aluminum (Al) and water has been regarded as an unwanted byproduct in the corrosion of $\mathrm{Al}$ metals. However, since the increasing demand of clean energy and mobile hydrogen storage system, the hydrogen produced from the reaction of $\mathrm{Al}$ and water becomes feasible and is an attractive study topic recently [1]. However, the generation of hydrogen gas from $\mathrm{Al} /$ water system is slow due to the thin layer of aluminum oxide on the surface of Al. The generation of hydrogen can be achieved by using highly corrosive basic solution such as sodium hydroxide $(\mathrm{pH}>13)$ [2]. Additives such as aluminum hydroxide [3], sodium stannate in sodium hydroxide solution [4], [5], hot water [6], $\mathrm{CaO}$ [7] were reported to be effective for enhanced generation of hydrogen, where serious corrosive conditions can be avoided. Alloying method such as Al-Ga alloys [8], [9], Bi doping [10], or milling additives such as $\mathrm{SnCl}_{2}$ [10] or $\mathrm{KCl} / \mathrm{NaCl}$ [11], and activated treatment on $\mathrm{Al}$ powders [12]-[14] are also employed to enhance the generation of hydrogen. However, these methods, accompanying with potential pollution, high cost and additional energy supply, are not very attractive. Z.Y. Deng et al. [15]-[18] reported that $\gamma-\mathrm{Al}_{2} \mathrm{O}_{3}$ is an excellent modifier for aluminum power for hydrogen generation. In their study, a powder mixture of $\mathrm{Al}$ and $\mathrm{Al}(\mathrm{OH})_{3}$ was used to sinter and form porous $\mathrm{Al} / \gamma-\mathrm{Al}_{2} \mathrm{O}_{3}$ composite. From his systematical studies [19], [20], it is known that smaller size of starting metal $\mathrm{Al}$ powder, higher temperature and coating with

Manuscript received June 1, 2014; revised August 16, 2014. This work was supported in part by the Ministry of Science and Technology, Taiwan, R.O.C. under the Grant \# 102-2113-M-033-008-MY3.

The authors are with the Department of Chemistry, Chung-Yuan Christian University, Chung-Li, 320, Taiwan, R.O.C. (corresponding author: H. W. Wang; e-mail: hongwen@ @ycu.edu.tw).
$\mathrm{Al}(\mathrm{OH})_{3}$ will greatly assist the hydrogen generation of $\mathrm{Al} /$ water system. He proposed [20] that hydroxide and oxides could dissociate water molecules and promote the hydration of the passive oxide film on $\mathrm{Al}$ particle surfaces.

In our previous studies [21]-[23], $\mathrm{Al}(\mathrm{OH})_{3}$ was proved to be very effective to promote hydrogen generation from $\mathrm{Al} /$ water system when it is in small size and low crystallinity. In the present study, in order to further enhance the effectiveness of $\mathrm{Al}(\mathrm{OH})_{3}$ powders on the reaction of $\mathrm{Al}$ and water, specially synthesized $\mathrm{Al}(\mathrm{OH})_{3}$ were evaluated. That is, to produce effective $\mathrm{Al}(\mathrm{OH})_{3}$ catalyst, molar ratio of precursors $\mathrm{Al}\left(\mathrm{NO}_{3}\right)_{3} / \mathrm{NaOH}$ has been studied. By using effective $\mathrm{Al}(\mathrm{OH})_{3}$ powders and a proper $\mathrm{Al} / \mathrm{Al}(\mathrm{OH})_{3} /$ water ratio, we are able to produce $\sim 100 \%$ yield of hydrogen within $120 \mathrm{~s}$ starting at room temperature.

\section{EXPERIMENTAL PROCEDURE}

Aluminum nitrate nonahydrate $\left(\mathrm{Al}\left(\mathrm{NO}_{3}\right)_{3} \cdot 9 \mathrm{H}_{2} \mathrm{O}, \geqq 98.0 \%\right.$, SHOWA), and sodium hydroxide $(\mathrm{NaOH}, \geqq 97 \%$, Sigma-Aldrich) were purchased and used for the preparation of aluminum hydroxide. Mole ratios of $\mathrm{Al}\left(\mathrm{NO}_{3}\right)_{3}$ to $\mathrm{NaOH}$ such as 1:3, 1:3.5, 1:4, 1:4.5, and 1:5 to produce $\mathrm{Al}(\mathrm{OH})_{3}$ powders were carried out at room temperature as well as in an ice bath. These aluminum hydroxides were evaluated their effects on the reaction of $\mathrm{Al} / \mathrm{H}_{2} \mathrm{O}$ system. Deionized (D.I.) water $(\mathrm{pH}=\sim 7.0$, resistivity $>18 \mathrm{M} \Omega \cdot \mathrm{cm})$, and metallic $\mathrm{Al}$ powders ( 325 mesh, purity $\geqq 99.5 \%$, APS $7-15 \mu \mathrm{m}$, CAS \# 7429-90-5, Alfa Aesar) were used for all experiments of hydrogen generation in this study.

Aluminum hydroxide is obtained by following well-known chemical reaction:

$$
\mathrm{Al}\left(\mathrm{NO}_{3}\right)_{3}+3 \mathrm{NaOH} \rightarrow 3 \mathrm{Na}\left(\mathrm{NO}_{3}\right)_{3}+\mathrm{Al}(\mathrm{OH})_{3}
$$

That is, $0.1 \mathrm{M} \mathrm{Al}\left(\mathrm{NO}_{3}\right)_{3}$ and $0.3 \sim 0.5 \mathrm{M} \mathrm{NaOH}$ were firstly produced in D.I. water. The $\mathrm{Al}\left(\mathrm{NO}_{3}\right)_{3}$ aqueous solution was gradually dripped into a $\mathrm{NaOH}$ solution by stirring for $24 \mathrm{~h}$ at room temperature (R.T.) or in an ice bath $\left(<5^{\circ} \mathrm{C}\right)$. The white precipitates $\mathrm{Al}(\mathrm{OH})_{3}$ was separated from the liquid by centrifugation. After wash twice using $0.01 \mathrm{M} \mathrm{HCl}$ aqueous solution and three times of D.I. water, the precipitates were freeze-drying for use.

Firstly, in order to search the best $\mathrm{Al}(\mathrm{OH})_{3}$ catalyst for hydrogen generation, experiments controlled at room temperature are carried out. One gram of various $\mathrm{Al}(\mathrm{OH})_{3}$ catalysts was put into a flask and $200 \mathrm{ml}$ D.I. water was added and shaken for a uniform mixture. One gram of $\mathrm{Al}$ powder was then added into this mixture for reaction. The temperature is kept constant by putting the flask in a circulated water bath $\left(25^{\circ} \mathrm{C} \pm 1{ }^{\circ} \mathrm{C}\right)$. The hydrogen generated 
was measured by a precision gas flow meter (Alicat Scientific, Inc.) connected after passing a condensing cold trap. Secondly, for the rapid hydrogen generation experiments, the best $\mathrm{Al}(\mathrm{OH})_{3}$ catalyst from the first study was used for the system $\mathrm{Al}: \mathrm{Al}(\mathrm{OH})_{3}: \mathrm{H}_{2} \mathrm{O}$ in the weight ratio 3:15:50 [23] without temperature control. The generation of hydrogen will be enhanced due to the in-situ exothermic reaction [23]. The water displacement method using two 2000-ml cylinder meters (reading data error $\pm 20 \mathrm{ml}$ ) was employed to measure the hydrogen generation because of the sharp speed of the generation rate.

To further understand the influence of synthesized $\mathrm{Al}(\mathrm{OH})_{3}$ powders on hydrogen generation, the activation energy for the reaction of $\mathrm{Al} /$ water system with/without catalyst were calculated. The powders were added to $200 \mathrm{ml}$ of deionized water and sealed in a conical flask. All of the experiments were carried out at $25 \pm 1^{\circ} \mathrm{C}, 35 \pm 1^{\circ} \mathrm{C}, 45 \pm 1^{\circ} \mathrm{C}$, $55 \pm 1^{\circ} \mathrm{C}$ using circulating water bath. No magnetic stirring was employed within the reaction flask. The hydrogen generated was measured using a silicone tube passing through a water bath at room temperature to the precision gas flow meter that automatically recorded the output data in a notebook computer every second until the reaction reached $100 \%$ yield of hydrogen $(=1360 \mathrm{ml}$ per $\mathrm{g}$ of $\mathrm{Al})$. The cooling water bath is used to minimize the water vapor.

The synthesized $\mathrm{Al}(\mathrm{OH})_{3}$ product powders were characterized with an analytical PW3040/60 X'Pert Pro $\mathrm{X}$-ray diffractometer using $\mathrm{Cu} \mathrm{K} \alpha$ radiation equipped a $\mathrm{Ni}$ filter over the angular range of $10^{\circ}-80^{\circ}(2 \theta)$ at a scanning rate of $4^{\circ} \mathrm{min}^{-1}$ and a step size of $0.01^{\circ}$. Field-emission scanning electron microscopy (FESEM, JEOL JSM 7600F) was employed to characterize the morphology of the powders.

\section{RESULTS AND DISCUSSION}

\section{A. Hydrogen Generation}

Fig. 1 shows the hydrogen generation from $1 \mathrm{~g} \mathrm{Al}$ in $200 \mathrm{ml}$ D.I. water with $1 \mathrm{~g}$ various $\mathrm{Al}(\mathrm{OH})_{3}$ catalysts, i.e. the reaction using weight ratio of $\mathrm{Al}: \mathrm{Al}(\mathrm{OH})_{3}: \mathrm{H}_{2} \mathrm{O}=1: 1: 200$ at room temperature. $\mathrm{pH}$ value of the solution is $\sim 9.5$. It shows that the $\mathrm{Al}(\mathrm{OH})_{3}$ from synthesized conditions such as $1: 3,1: 4.5$, and 1:5 are not good. The $\mathrm{Al}(\mathrm{OH})_{3}$ obtained at $1: 3.5$ and $1: 4$ are helpful to hydrogen generation. In particularly, synthesis ratio of 1:3.5 and 1:4 in ice bath enhances the catalytic effect. The synthesized ratio without caption is referred to those synthesized at room temperature condition.

In the rapid generation experiments without temperature control, i.e., $\mathrm{Al}: \mathrm{Al}(\mathrm{OH})_{3}: \mathrm{H}_{2} \mathrm{O}$ in the weight ratio 3:15:50, we firstly demonstrate the hydrogen generation without using $\mathrm{Al}(\mathrm{OH})_{3}$ catalyst at $50 \mathrm{ml}$ D.I. water at $\mathrm{pH}=12.6$ using $3 \mathrm{~g} \mathrm{Al}$, as shown in Fig. 2. It is clear that, in this condition, the reaction takes more than $20 \mathrm{~h}$ to generate hydrogen significantly. We also conducted experiments at $\mathrm{pH}$ value lower than 12. As expected, without using $\mathrm{Al}(\mathrm{OH})_{3}$ catalyst at a solution with $\mathrm{pH} \leq 12$, it is hardly observe any significant hydrogen generation from $3 \mathrm{~g} \mathrm{Al} / 50 \mathrm{ml}$ D.I. water system in a reasonable duration (> $30 \mathrm{~h})$. However, when $\mathrm{Al}(\mathrm{OH})_{3}$ is used, the situation is dramatically different. Fig. 3 shows the effect of $\mathrm{Al}(\mathrm{OH})_{3}$ derived from 1:4 ratio on the hydrogen generation. It is clear that $\mathrm{Al}(\mathrm{OH})_{3}$ in ice bath assists $\sim 100 \%$ yield of hydrogen from $\mathrm{Al} /$ water reaction within $120 \mathrm{~s}$.

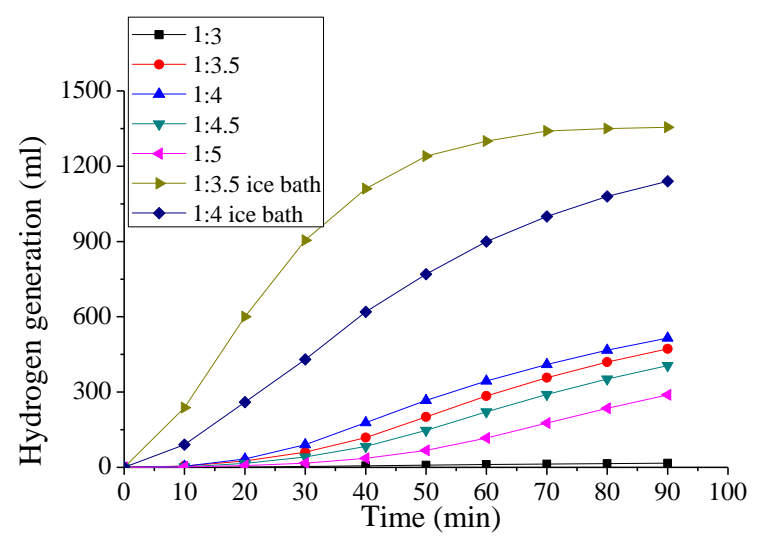

Fig. 1. Effect of $\mathrm{Al}(\mathrm{OH})_{3}$ from various synthesis conditions on the hydrogen generation at room temperature. Weight ratio of the reaction system, $\mathrm{Al}: \mathrm{Al}(\mathrm{OH})_{3}: \mathrm{H}_{2} \mathrm{O}=1: 1: 200$.

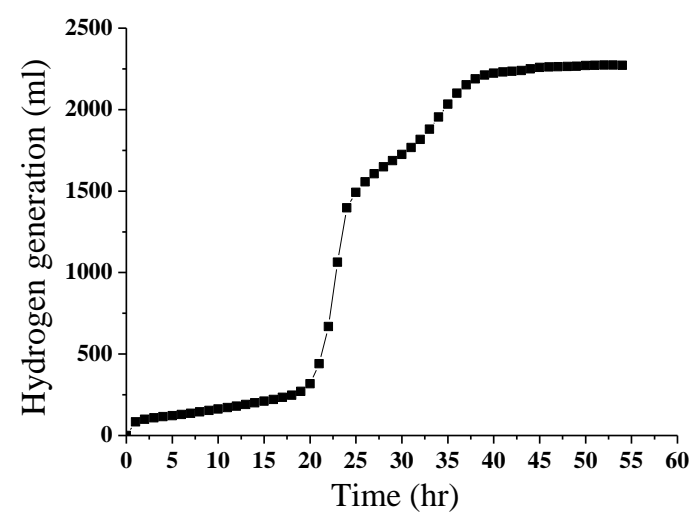

Fig. 2. $3 \mathrm{~g} \mathrm{Al}$ in $50 \mathrm{ml}$ D.I. water at $\mathrm{pH}=12.6$, hydrogen will only be generated significantly after 20 hours duration.

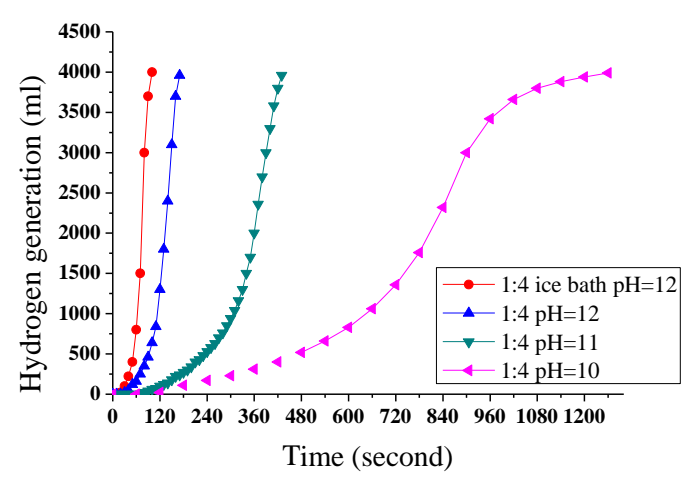

Fig. 3. For rapid hydrogen generation experiments, $\mathrm{Al}: \mathrm{Al}(\mathrm{OH})_{3}: \mathrm{H}_{2} \mathrm{O}=$ 3:15:50 is used. At $\mathrm{pH}=12$, synthesized $\mathrm{Al}(\mathrm{OH})_{3}(1: 4)$ in ice bath assists hydrogen production in $120 \mathrm{~s}$.

$\mathrm{Al}(\mathrm{OH})_{3}$ synthesized at $1: 4$ at room temperature takes about $180 \mathrm{~s}$ to yield over $95 \% \mathrm{H}_{2}$ production. The hydrogen generation peak rate is as high as $2000 \mathrm{ml}$ per $3 \mathrm{~g} \mathrm{Al} \cdot \mathrm{min}^{-1}$ $\left(\sim 667 / \mathrm{g} \cdot \mathrm{Al} \cdot \mathrm{min}^{-1}\right)$ when $1: 4$ ice bath $\mathrm{Al}(\mathrm{OH})_{3}$ is used in the 3:15:50 reacting system. With $\mathrm{Al}(\mathrm{OH})_{3}$ catalyst, solution with $\mathrm{pH}<12$ such as 11 and 10 will take a little more time, as shown in Fig. 3. In these low $\mathrm{pH}$ conditions, without using $\mathrm{Al}(\mathrm{OH})_{3}$ catalyst, we cannot observe such rapid generation of hydrogen. Fig. 3 obviously demonstrates the significance of catalyst $\mathrm{Al}(\mathrm{OH})_{3}$ on the hydrogen generation from $\mathrm{Al} /$ water system.

The $\mathrm{Al}(\mathrm{OH})_{3}$ synthesized at ratio 1:3.5 and 1:4 in ice bath are very effective catalysts to promote hydrogen generation from Al/water system. Their effectiveness are shown in Fig. 4 and Fig. 5, respectively. In Fig. 4, we demonstrate the over 
95\% yield of hydrogen from $3 \mathrm{~g} \mathrm{Al} / 50 \mathrm{ml} \mathrm{H}_{2} \mathrm{O}$ system within $100 \mathrm{~s}$. Furthermore, the consecutive addition of the second batch of $3 \mathrm{~g} \mathrm{Al}$ in the exact same solution, where the temperature is raised to more than $70^{\circ} \mathrm{C}$ due to the first $3 \mathrm{~g} \mathrm{Al}$ reaction, produces hydrogen at even faster rate. When the temperature is slightly dropped to $50^{\circ} \mathrm{C}$, we then add the third batch $3 \mathrm{~g} \mathrm{Al}$ powder into the solution. The over $95 \%$ yield of hydrogen is still very rapid ( $40 \mathrm{~s}$ ), as shown in Fig. 4 . The reason for faster generation rate from the consecutive batches can be explained by the help of high temperature. The catalytic effect of $\mathrm{Al}(\mathrm{OH})_{3}$ obtained at 1:4 in ice bath is quite similar to that of 1:3.5 in ice bath, as shown in Fig. 5. From the results of Fig. 1, Fig. 4 and Fig. 5, we could conclude that the different effectiveness of $\mathrm{Al}(\mathrm{OH})_{3}$ synthesized at 1:3.5 and 1:4 in ice bath can only be appreciated at slow reaction system using $200 \mathrm{ml}$ water, and are both quite effective at rapid reaction system.

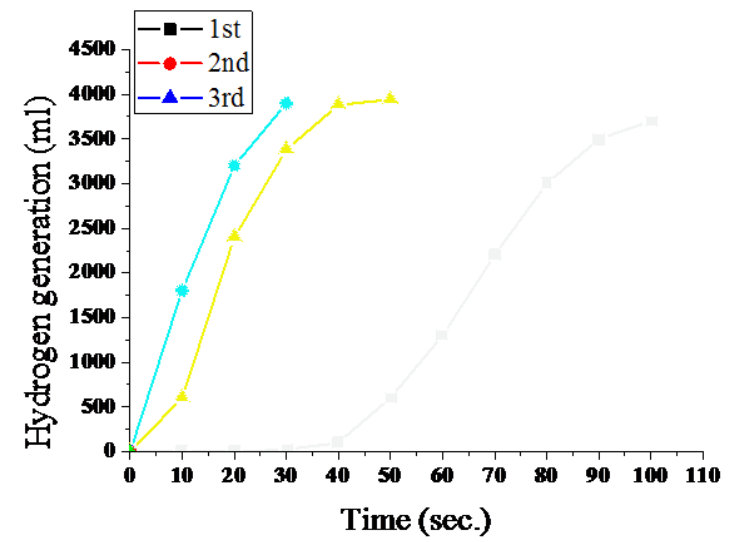

Fig. 4. $\mathrm{Al}(\mathrm{OH})_{3}(1: 3.5)$ in ice bath assists the hydrogen generation over $95 \%$ yield of $3 \mathrm{~g} \mathrm{Al} / 50 \mathrm{ml} \mathrm{H}_{2} \mathrm{O}$ system in $100 \mathrm{~s}$. The consecutive batches, the $2^{\text {nd }}$ and $3^{\text {rd }}$, are even faster than the first one, which yield $95 \%$ hydrogen in $30 \mathrm{~s}$ and $40 \mathrm{~s}$, respectively.

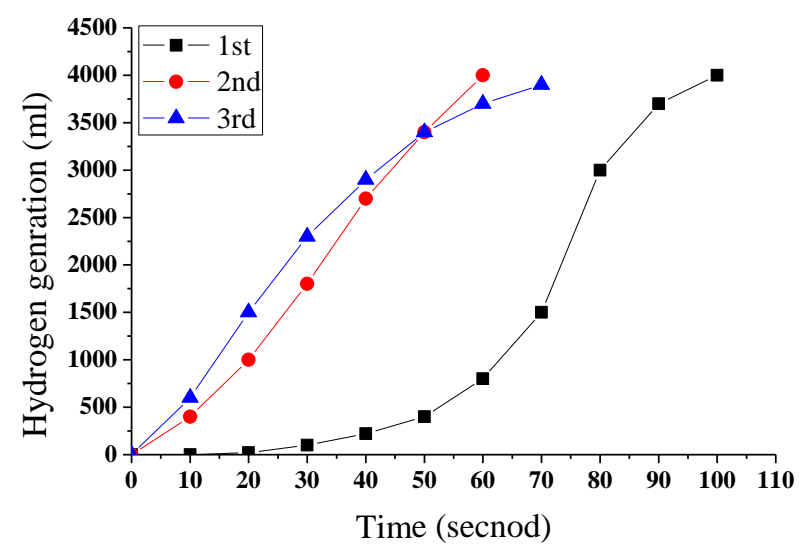

Fig. 5. $\mathrm{Al}(\mathrm{OH})_{3}(1: 4)$ in ice bath also exhibits similar catalytic effect to those of 1:3.5 in Fig. 4. Hydrogen production is over $95 \%$ yield in $100 \mathrm{~s}$. The consecutive batches, the $2^{\text {nd }}$ and $3^{\text {rd }}$, yield $95 \%$ hydrogen around $60 \mathrm{~s}$.

\section{B. Characteristics of $\mathrm{Al}(\mathrm{OH})_{3}$ and Mechanism of Enhancement}

Fig. 6 shows the XRD results for the synthesized $\mathrm{Al}(\mathrm{OH})_{3}$ powders. All synthesized $\mathrm{Al}(\mathrm{OH})_{3}$ powders are crystalline. The dots denotes the gibbsite phase ( $\alpha$ phase). Only the 1:3 is relatively weak. For the ratios $1: 4.5$, and $1: 5$, there are mixed phases of gibbsite and bayerite ( $\beta$ phase). For the ratios 1:4, $1: 3.5$, and $1: 3$, the crystalline phase are mainly bayerite. Those crystalline phases obtained in ice bath are more or less the same as those of room temperature. However, the intensity peak height of ice bath is slightly less than those obtained at room temperature, as shown in Fig. 7. From Fig. 6, we observed that the higher $\mathrm{NaOH}$ concentration resulted in the formation of mixed phase $(\alpha+\beta)$. The effect of gibbsite $(\alpha)$ and bayerite $(\beta)$ on the hydrogen generation of $\mathrm{Al} /$ water system still needs further investigation. However, since their crystal structures differ only in the way that the double layers of coordinated $\mathrm{OH}^{-}$and $\mathrm{Al}^{+3}$ are stacked to form the three dimensional crystal units [24]. It is not our intention to study these differences in this study. However, since the best catalytic effect comes from 1:3.5 and 1:4, obtained either at room temperature or ice bath, it is then the focus of our following discussion.

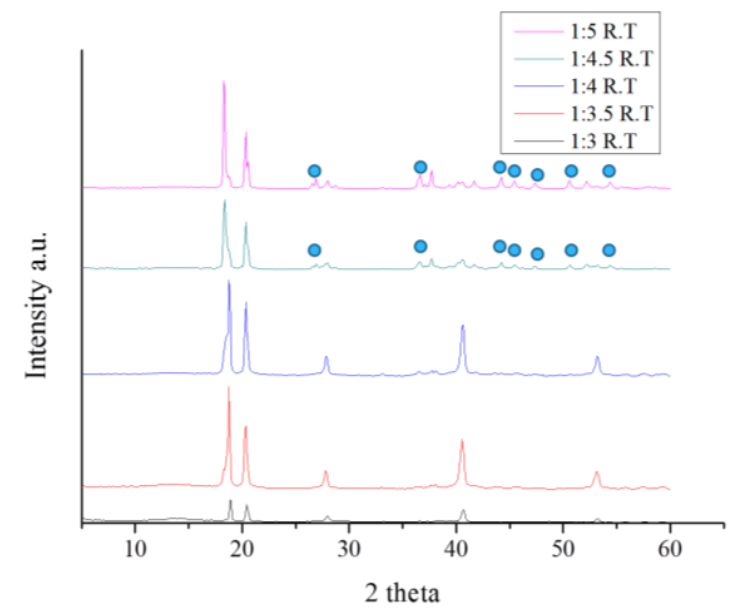

Fig. 6. XRD of $\mathrm{Al}(\mathrm{OH})_{3}$ synthesized using various molar ratios at room temperature.

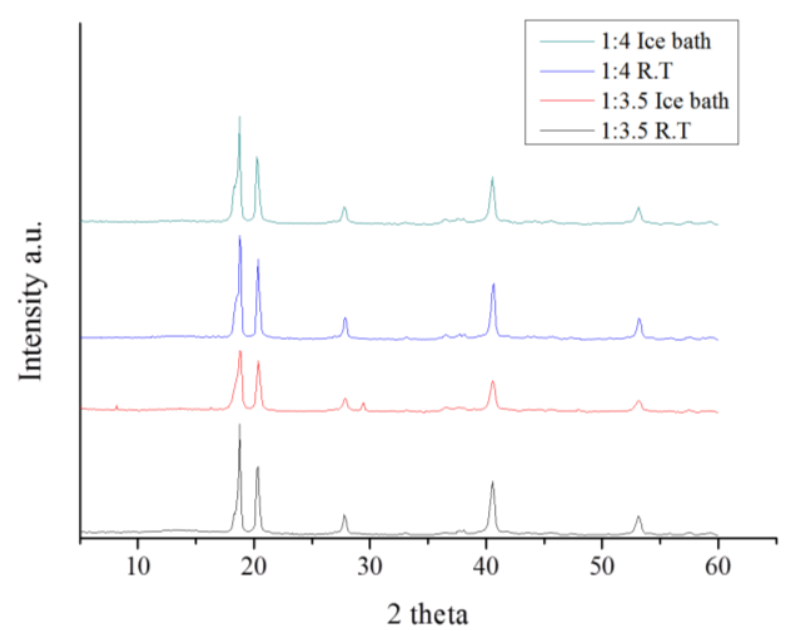

Fig. 7. Compare the intensity of $\mathrm{Al}(\mathrm{OH})_{3}$ obtained at room temperature and those in ice bath. Those synthesized in ice bath is slightly in lower intensity.

Fig. 8 shows FESEM morphologies of various synthesized $\mathrm{Al}(\mathrm{OH})_{3}$ powders. It is clear that $1: 4.5$ and $1: 5$ at room temperature have large rod-like crystals, while the 1:3.5 and 1:4 are plate-like. The 1:3 R.T. image shows small and round shaped particles. The ratio 1:3.5 and 1:4 in ice bath exhibits much smaller plate-like crystals than their counterparts obtained at room temperature, as shown in Fig. 8.

The plate-like crystals of 1:3.5 and 1:4, obtained either at room temperature or in ice bath, may play an important role on the assistance to the hydrogen generation from $\mathrm{Al} /$ water system. It is then considered that edges and corners of the hexagonal plate-like crystal structure are the active sites for the dissociation of water molecules into $\mathrm{OH}^{-}$and $\mathrm{H}^{+}$. The mechanism scheme can be depicted in Fig. 9. 

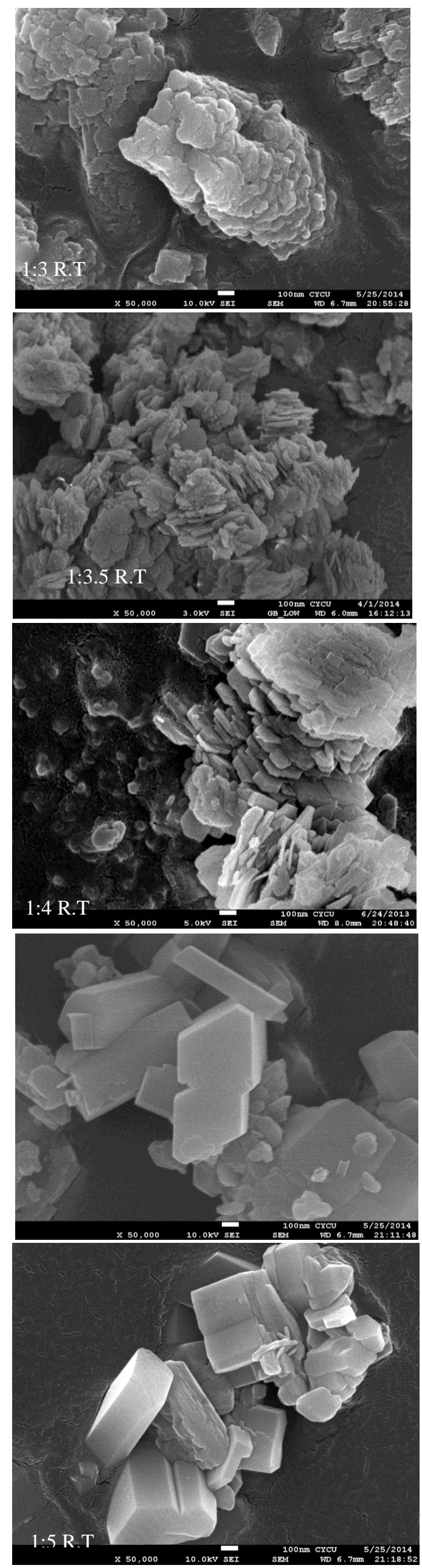
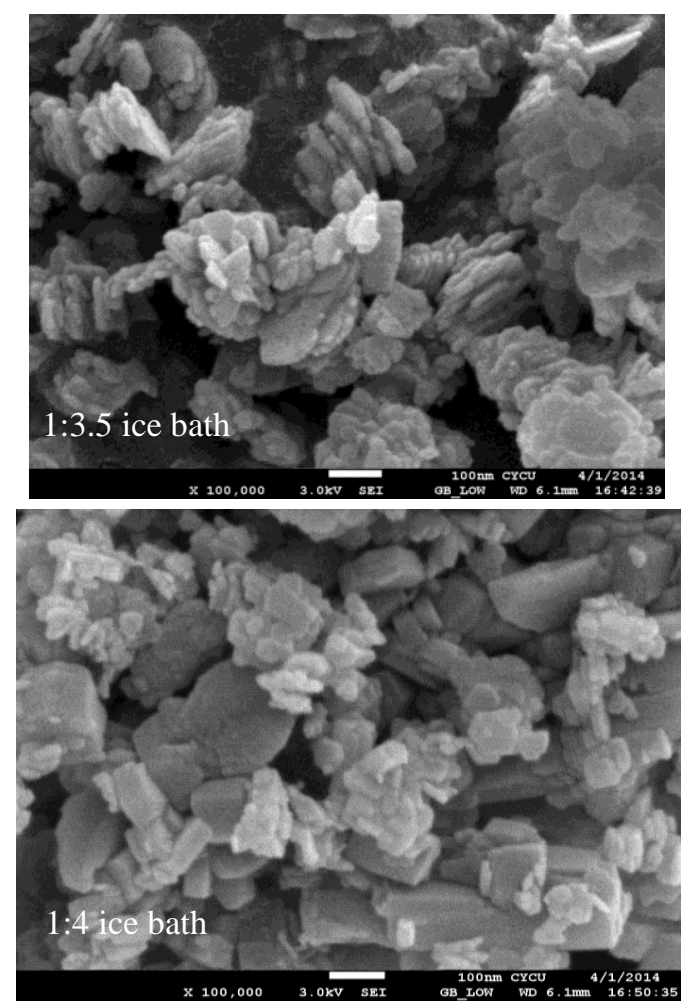

Fig. 8. FESEM for the synthesized $\mathrm{Al}(\mathrm{OH})_{3}$ powders. The synthesized condition is denoted in white texts at the lower left corner.

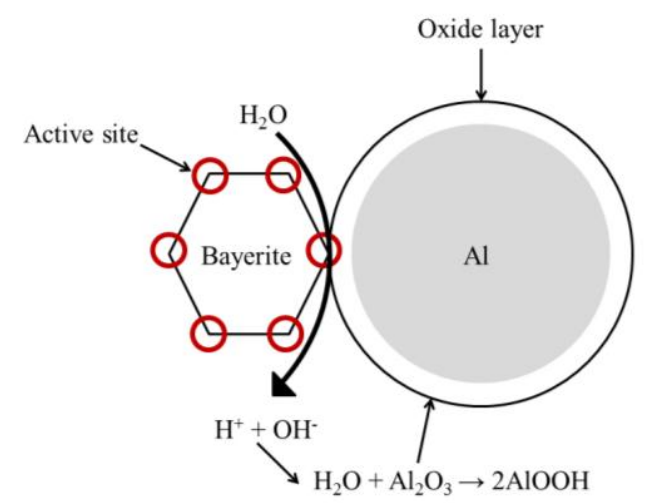

Fig. 9. Mechanism of enhanced hydrogen generation via the easy hydration process of the passive oxide film on $\mathrm{Al}$ particle surface under the assistance of bayerite in aqueous solution.

The higher surface area of $\mathrm{Al}(\mathrm{OH})_{3}$ obtained at 1:3.5 and 1:4 in ice bath may further enhance these activities of plate-like crystals in the hydrogen generation of $\mathrm{Al} /$ water system. The surface area of $\mathrm{Al}(\mathrm{OH})_{3}$ powders derived from 1:3.5 and 1:4 is shown in Table I. Ratio 1:3.5 results in higher surface area than that of $1: 4$. The ice both condition increases the activity of these plate-like crystals by reducing their sizes. To further elucidate the influences of these plate-like crystals, activation energies of the hydrogen generation using various $\mathrm{Al}(\mathrm{OH})_{3}$ were calculated.

TABLE I: SURFACE AREA, AND ACTIVATION ENERGY FOR HYDROGEN GENERATION FOR SYNTHESIZED ALUMINUM HYDROXIDE POWDERS

\begin{tabular}{|l|l|l|}
\hline $\mathbf{A l}(\mathbf{O H})_{3}$ & $\begin{array}{l}\text { B.E.T. } \\
\left(\mathbf{m}^{2} / \mathbf{g}\right)\end{array}$ & $\begin{array}{l}\text { *Activation } \\
\text { Energy }(\mathbf{k J} / \mathbf{m o l e})\end{array}$ \\
\hline 1:3.5 R.T & 23.19 & 45.14 \\
\hline 1:3.5 ice bath & 39.86 & 33.25 \\
\hline 1:4 R.T & 7.00 & 47.07 \\
\hline 1:4 ice bath & 12.74 & 35.40 \\
\hline
\end{tabular}

*Activation energy for $\mathrm{Al}$ in D.I. water without $\mathrm{Al}(\mathrm{OH})_{3}$ is $158 \mathrm{~kJ} / \mathrm{mole}$.

The activation energy can be derived from Arrhenius 
equation: $k=\mathrm{A} \cdot \exp \left(-\mathrm{E}_{\mathrm{a}} / \mathrm{RT}\right)$, slope $=-\mathrm{E}_{\mathrm{a}} / \mathrm{R}$, where $\mathrm{Ea}$ is the activation energy. $k$ is the rate constant at $25,35,45$, and $55^{\circ} \mathrm{C}$, using $200 \mathrm{ml}$ D.I. water and temperature controlled system. Take $1 \mathrm{~g}$ pure $\mathrm{Al}$ in $200 \mathrm{ml}$ D.I. water as an example, as shown in Fig. 10 (a) and (b), respectively. We have obtained an activation energy of $158 \mathrm{~kJ} /$ mole for pristine $\mathrm{Al}$ in water, i.e. without using $\mathrm{Al}(\mathrm{OH})_{3}$ catalyst. In this way, we are able to calculate the activation energy of hydrogen generation when $\mathrm{Al}(\mathrm{OH})_{3}$ is used in $200 \mathrm{ml}$ water system. It is concluded that $1: 3.5$ and $1: 4$ in ice bath have the lowest activation energy for hydrogen generation, as shown in Table I.

It is considered that the small size and sharp edge of the randomly stacking hexagonal plate-like crystals of $\mathrm{Al}(\mathrm{OH})_{3}$ render the crystal edges and corners very active on the dissociation of water molecules into $\mathrm{OH}^{-}$and $\mathrm{H}^{+}$. The special morphology of $\mathrm{Al}(\mathrm{OH})_{3}$ is considered to be very effective to react with dense $\mathrm{Al}_{2} \mathrm{O}_{3}$ protecting layer on the metal $\mathrm{Al}$ particles that in turn assists the following reaction we proposed [22]:

$$
\mathrm{Al}_{2} \mathrm{O}_{3}+\mathrm{Al}(\mathrm{OH})_{3} \rightarrow 3 \mathrm{AlO}(\mathrm{OH})
$$

The boehmite $\mathrm{AlO}(\mathrm{OH})$ could readily reacts with fresh metal $\mathrm{Al}$ as follows:

$$
2 \mathrm{Al}+6 \mathrm{AlO}(\mathrm{OH}) \rightarrow 4 \mathrm{Al}_{2} \mathrm{O}_{3}+3 \mathrm{H}_{2}
$$

By utilizing special synthesized catalyst $\mathrm{Al}(\mathrm{OH})_{3}$ and the in-situ exothermic reaction of $\mathrm{Al} /$ water system, we are able to produce over $95 \%$ yield of hydrogen within $100 \mathrm{~s}$ at a solution with $\mathrm{pH}=12$.

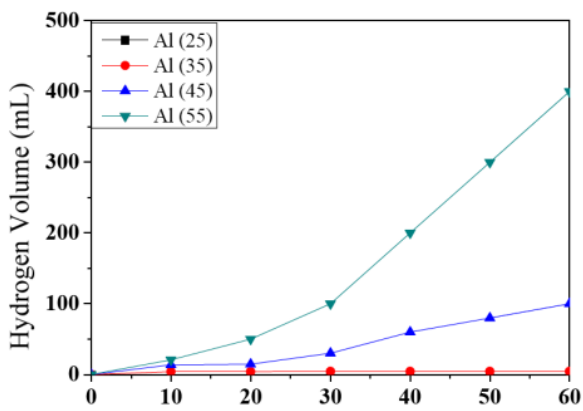

(a)

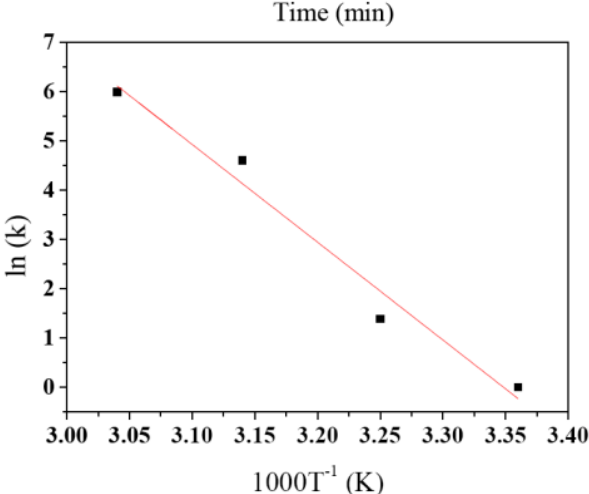

(b)

Fig. 10. (a) hydrogen generation vs. duration for pristine $1 \mathrm{~g} \mathrm{Al}$ in $200 \mathrm{ml}$ D.I. water, (b) rate constant at different temperatures.

\section{CONCLUSIONS}

We have demonstrated the novel catalytic effect of $\mathrm{Al}(\mathrm{OH})_{3}$ powders on the hydrogen generation from $\mathrm{Al} / \mathrm{H}_{2} \mathrm{O}$ system. When $\mathrm{Al}(\mathrm{OH})_{3}$ powders were obtained from a ratio $\mathrm{Al}\left(\mathrm{NO}_{3}\right)_{3}: \mathrm{NaOH}=1: 3.5 \sim 1: 4$, the small size and sharp edge of the hexagonal plate-like crystals promotes the hydrogen generation from $\mathrm{Al} /$ water system significantly. This special morphology of $\mathrm{Al}(\mathrm{OH})_{3}$ is considered to be very effective to react with dense $\mathrm{Al}_{2} \mathrm{O}_{3}$ layer on $\mathrm{Al}$ particles. In addition, when an optimum combination of $\mathrm{Al} / \mathrm{Al}(\mathrm{OH})_{3} /$ water (3:15:50) for hydrogen generation is employed, the self-heating exothermic reaction from a large quantity of initial Al powder in a minimum water is able to produce high temperature more than $90^{\circ} \mathrm{C}$ and consequently succeed in rapid hydrogen generation ( $\geq 95 \%$ yield within $100 \mathrm{~s}$ ), making this system an ideal candidate for a hydrogen source in a use-on-demand system.

\section{ACKNOWLEDGEMENTS}

We appreciate the financial support from Ministry of Science and Technology, Taiwan, R.O.C. Grant number: NSC102-2113-M-033 -008-MY3

\section{REFERENCES}

[1] P. P. Edwards, V. L. Kuznetsov, W. I. F. David, and N. P. Brandon, "Hydrogen and fuel cells: Towards a sustainable energy future," Energy Policy, vol. 36, pp. 4356-4362, 2008.

[2] D. Belitskus, "Reaction of Aluminum with Sodium Hydroxide Solution as a Source of Hydrogen," J. Electrochemical Soc., vol. 117, pp.1097-1099, 1970.

[3] L. Soler, A. M. Candela, J. Macanas, M. Munoz, and J. Casado, "Hydrogen generation by aluminum corrosion in seawater promoted by suspensions of aluminum hydroxide," Int. J. Hydrogen Energy, vol. 34, pp. 8511-8518, 2009.

[4] L. Soler, A. M. Candela, J. Macanas, M. Munoz, and J. Casado, "Hydrogen generation from water and aluminum promoted by sodium stannate," Int. J. Hydrogen Energy, vol. 35, pp. 1038-1048, 2010.

[5] H. B. Dai, G. L. Ma, H. J. Xia, and P. Wang, "Reaction of aluminum with alkaline sodium stannate solution as a controlled source of hydrogen," Energy Environ Sci., vol. 4, pp. 2206-2212, 2011.

[6] S. S. Razavi-Tousi and J. A. Szpunar, "Mechanism of corrosion of activated aluminum particlesby hot water," Electrochimica Acta, vol. 127, pp. 95-105, 2014.

[7] X. Y. Chen, Z. W. Zhao, M. M. Hao, and D. Z. Wang, "Research of hydrogen generation by the reaction of Al-based materials with water," Journal of Power Sources, vol. 222, pp. 188-195, 2013.

[8] J. T. Ziebarth, J. M. Woodall, R. A. Kramer, and G. Choi, "Liquid phase-enabled reaction of Al-Ga and Al-Ga-In-Sn alloys with water," Int. J Hydrogen Energ, vol. 36, pp. 5271-5279, 2011.

[9] W. Wang, X. M. Zhao, D. M. Chen, and K. Yang, "Insight into the reactivity of Al-Ga-In-Sn alloy with water," Int. J Hydrogen Energ, vol. 37, pp. 2187-2194, 2012.

[10] F. Xu, L. X. Sun, X. F. Lan et al., "Mechanism of fast hydrogen generation from pure water using $\mathrm{Al}-\mathrm{SnCl}_{2}$ and $\mathrm{Bi}$-doped $\mathrm{Al}-\mathrm{SnCl}_{2}$ composites," Inter. J. Hydrogen Energy, vol. 39, pp. 5514-5521, 2014.

[11] B. Alinejad and K. Mahmoodi, "A novel method for generating hydrogen by hydrolysis of highly activated aluminum nanoparticles in pure water," Int. J. Hydrogen Energy, vol. 34, pp.7934-7938, 2009.

[12] V. Rosenband and A. Gany, "Application of activated aluminum powder for generation of hydrogen from water," Int. J. Hydrogen Energy, vol. 35, pp. 10898-10904, 2010.

[13] K. Mahmoodi and B. Alinejad, "Enhancement of hydrogen generation rate in reaction of aluminum with water," Int. J. Hydrogen Energy, vol. 35 , pp. 5227-5232, 2010.

[14] A. V. Parmuzina and O. V. Kravchenko, "Activation of aluminum metal to evolve hydrogen from water," Int. J. Hydrogen Energy, vol. 33, pp. 3073-3076, 2008

[15] Z. Y. Deng, Y. F. Liu, Y. Tanaka, J. H. Ye, and Y. Sakka, "Modification of $\mathrm{Al}$ particle surfaces by $\gamma-\mathrm{Al}_{2} \mathrm{O}_{3}$ and its effect on the corrosion behavior of Al," J. Amer. Ceram. Soc., vol. 88, no. 4, pp. 977-979, 2005.

[16] Z. Y. Deng, Y. F. Liu, Y. Tanaka, H. W. Zhang, J. H. Ye, and Y. Kagwa, "Temperature effect on hydrogen generation by the reaction of $\gamma$ - $\mathrm{Al}_{2} \mathrm{O}_{3}$-modified $\mathrm{Al}$ powder with distilled water," J. Amer. Ceram. Soc., vol. 88, no. 10, pp. 2975-2977, 2005. 
[17] Z. Y. Deng, J. M. F. Ferreira, Y. Tanaka, and J. H. Ye, "Physicochemical Mechanism for the Continuous Reaction of $\gamma-\mathrm{Al}_{2} \mathrm{O}_{3}$ Modified Aluminum Powder with Water," J. Amer. Ceram. Soc., vol. 90, no. 5, pp. 1521-1526, 2007.

[18] Z. Y. Deng, Y. B. Tang, L. L. Zhu, Y. Sakka, and J. H. Ye, "Effect of different modification agents on hydrogen-generation by the reaction of Al with water," Int. J. Hydrogen Energy, vol. 35, pp. 9561-9568, 2010.

[19] C. S. Fang, W. Z. Gai, and Z. Y. Deng, "Al Surface Modification by a Facile Route,” J. Am. Ceram. Soc., vol. 97, no. 1, pp. 44-47, 2014.

[20] W. Z. Gai, C. S. Fang, and Z. Y. Deng, "Hydrogen generation by the reaction of Al with water using oxides as catalysts," Int. J. Energy Res., vol. 38, pp. 918-925, 2014.

[21] H. W. Wang, H. W. Chung, H. T. Teng, and G. Cao, "Generation of hydrogen from aluminum and water - Effect of metal oxide nanocrystals and water quality," Int. J. Hydrogen Energy, vol. 36, pp. 15136-15144, 2011.

[22] H. T. Teng, T. Y. Lee, Y. K. Chen, H. W. Wang, and G. Cao, "Effect of $\mathrm{Al}(\mathrm{OH})_{3}$ on the hydrogen generation of aluminum-water system," $J$. Power Sources, vol. 219, pp. 16-21, 2012.

[23] Y. K. Chen, H. T. Teng, T. Y. Lee, and H. W. Wang, "Rapid hydrogen generation from aluminum-water system by adjusting water ratio to various aluminum/aluminum hydroxide," Int J Energy Environ Eng, vol. 5, p. 87, 2014.

[24] S. Goldberg, J. A. Davis, and J. D. Hem, The Environment Chemistry of Aluminum, G. Sposito, Ed., Lewis Publishing, 1996, ch. 7, pp. 271-331.

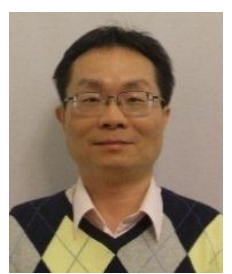

H. W. Wang received his B.S. degree from Department of Metallurgy and Materials Science, National Cheng-Kung University in 1985, M.S degree from the Department of Materials Science and Engineering, National Tsing-Hwa University in 1987 in Taiwan and Ph.D. degree from Materials Science Centre, University of Manchester in U.K in 1993. Before joining Chung-Yuan Christian University in 1999, He was a scientist in Industrial Technology Research Institutes (ITRI), Hsinchu, Taiwan. He became a professor in 2007 and was the director of Center for Nanotechnology at CYCU during 2007-2009. Prof. Wang's research interests include the processing, and electrical properties of dielectric ceramic and metal oxides materials. His research involved ceramic powder processing, graphene synthesis, and thin films through chemical solutions such as sol-gel, and microwave hydrothermal process. The applications of materials he involved are mainly in Perovskite solar cells, and hydrogen generation.

Professor Wang was awarded a 2008 Endeavour Executive Award offered by The Department of Education (DEST), Australia Government. He has been a visiting scholar in University of Washington, Seattle, U.S.A (2005, 2011 summer), Toyama Perfectural University, Toyama, Japan (2006 summer), and University of Sydney, Sydney, Australia (2008 summer). He has published more than $60 \mathrm{SCI} / \mathrm{EI}$ scientific papers and filed 8 patents. 